\title{
Flunarizine: a review of its role in migraine prophylaxis
}

\author{
M. V. Francis ${ }^{1}$, Sumit Singh ${ }^{2}$, Vishal Goyal ${ }^{3}$, Mukundraj Keny ${ }^{3 *}$
}

\begin{abstract}
${ }^{1}$ Department of Headache and Neuroophthalmology, Teresa Eye and Migraine Centre, Cherthala, Kerala, India ${ }^{2}$ Department of Neurology, Artemis Institute of Neurosciences, Gurugram, Haryana, India

${ }^{3}$ Department of Medical Affairs, Janssen, Johnson and Johnson Private Limited, Mumbai, Maharashtra, India
\end{abstract}

Received: 09 December 2019

Revised: 27 December 2019

Accepted: 31 December 2019

\section{*Correspondence:}

Dr. Mukundraj Keny,

E-mail: mkeny@its.jnj.com

Copyright: ( ) the author(s), publisher and licensee Medip Academy. This is an open-access article distributed under the terms of the Creative Commons Attribution Non-Commercial License, which permits unrestricted non-commercial use, distribution, and reproduction in any medium, provided the original work is properly cited.

\begin{abstract}
Flunarizine, a potent calcium channel blocker has been used for more than three decades for the prophylactic management of migraine. Theories suggest that flunarizine may act through multiple mechanisms such as inhibition of cortical spreading depression, neurogenic inflammation and channelopathy. Flunarizine is efficacious in the management of various types of migraines such as common, classical, vestibular, abdominal, hemiplegic and pediatric migraine. It has a manageable safety profile with weight gain and drowsiness being commonly reported.
\end{abstract}

Keywords: Calcium channel, Channelopathy, Flunarizine, Hemiplegic, Migraine, Prophylaxis

\section{INTRODUCTION}

Migraine is a neurovascular disorder characterized by unilateral pulsating headache, photophobia and/or phonophobia, nausea/vomiting and often preceded by aura. ${ }^{1}$ The prevalence of the disease in India is $14.12 \%$ to $25.2 \% .^{2,3}$ Studies conducted in South Indian population have shown that prevalence of migraine in women is more than $35 \%$, which is strikingly high as compared to the Western population ${ }^{4}$

Flunarizine, a calcium channel blocker is prescribed worldwide for migraine prophylaxis for more than 30 years and has demonstrated efficacy and safety in different migraine types and patient populations. ${ }^{5,6}$ It is approved in various countries and included in numerous national migraine prophylaxis treatment guidelines, ${ }^{5,7-9}$ This article aims to update the medical practitioners regarding the role of flunarizine in migraine prophylaxis and the evidences that discuss the efficacy and safety of flunarizine.

\section{REVIEW OF LITERATURE \\ Flunarizine: guideline recommendations}

Various clinical practice guidelines recommend flunarizine as a first line drug for migraine prophylaxis in adults and pediatric population. Flunarizine-related clinical evidence has also been supported by systematic reviews and standard medical textbooks. (Table 1)

\section{Flunarizine: role in migraine theories}

Flunarizine has been proposed to act on the theories of channelopathy, cortical spreading depression and neurogenic inflammation by blocking the neuronal $\mathrm{Ca}+2$ channels. (Figure 1). 
Table 1: Recommendations for use of flunarizine in migraine.

\begin{tabular}{|c|c|}
\hline Guideline/Review/Books & Recommendation \\
\hline \multicolumn{2}{|l|}{ Guidelines } \\
\hline $\begin{array}{l}\text { American Academy of Neurology (AAN) } \\
\text { Guidelines 2004: Quality Standards Sub- } \\
\text { Committee and Practice Committee of the Child } \\
\text { Neurology Society }{ }^{23}\end{array}$ & $\begin{array}{l}\text { Flunarizine has been evaluated for several trials in childhood } \\
\text { migraine and can be considered for this purpose but it is not } \\
\text { available in the United States. (Class I, Level B) } \\
\text { There is insufficient evidence to make any recommendations } \\
\text { concerning the use of amitriptyline, divalproex sodium, } \\
\text { topiramate and propranolol }\end{array}$ \\
\hline $\begin{array}{l}\text { Recommendations of the German Society for } \\
\text { Neurology and the German Migraine and } \\
\text { Headache Society }{ }^{29}\end{array}$ & $\begin{array}{l}\text { Flunarizine is recommended as one of the drugs of first choice } \\
\text { in prophylaxis of migraine }\end{array}$ \\
\hline $\begin{array}{l}\text { European Federation of Neurological Societies } \\
\text { Guidelines } 2009^{8}\end{array}$ & $\begin{array}{l}\text { Class A evidence suggest that flunarizine is a first-choice drug } \\
\text { in migraine prophylaxis }\end{array}$ \\
\hline Italian guideline for primary headaches ${ }^{30}$ & $\begin{array}{l}\text { Flunarizine is recommended as a class I medication for } \\
\text { migraine }\end{array}$ \\
\hline $\begin{array}{l}\text { Danish Headache Society-diagnosis and } \\
\text { treatment of headache disorders }\end{array}$ & $\begin{array}{l}\text { For migraine prophylaxis flunarizine could be in the first line } \\
\text { of treatment }\end{array}$ \\
\hline $\begin{array}{l}\text { National Institute of Care and Excellence } \\
\text { guidelines 2014- Migraine prophylaxis: } \\
\text { flunarizine }\end{array}$ & $\begin{array}{l}\text { Flunarizine has comparable efficacy as propranolol or } \\
\text { topiramate in reducing the frequency of migraines in adults }\end{array}$ \\
\hline $\begin{array}{l}\text { Clinical Practice Guidelines. Diagnosis and } \\
\text { Management of Headache by Ministry of Health, } \\
\text { Singapore. } 2007^{33}\end{array}$ & $\begin{array}{l}\text { Grade A evidence suggest that flunarizine could be used for } \\
\text { migraine prophylaxis }\end{array}$ \\
\hline $\begin{array}{l}\text { Guidelines on the diagnosis and the current } \\
\text { management of headache and related disorders } \\
\text { Indian expert panel }{ }^{34}\end{array}$ & $\begin{array}{l}\text { Flunarizine could be used as a first line migraine prophylactic } \\
\text { drug }\end{array}$ \\
\hline \multicolumn{2}{|l|}{ Review } \\
\hline $\begin{array}{l}\text { Cochrane Database System Reviews 2003: Drugs } \\
\text { for preventing migraine headaches in children }{ }^{35}\end{array}$ & $\begin{array}{l}\text { Flunarizine is the only agent that has been studied in rigorous } \\
\text { controlled trials and found to be effective in childhood } \\
\text { migraine }\end{array}$ \\
\hline \multicolumn{2}{|l|}{ Book } \\
\hline $\begin{array}{l}\text { Harrison's Textbook of Internal Medicine } \\
\text { 20th Edition } \\
36\end{array}$ & $\begin{array}{l}\text { Flunarizine is effective in migraine prevention. It is not } \\
\text { available in the US. Local guidelines to be considered for use }\end{array}$ \\
\hline
\end{tabular}

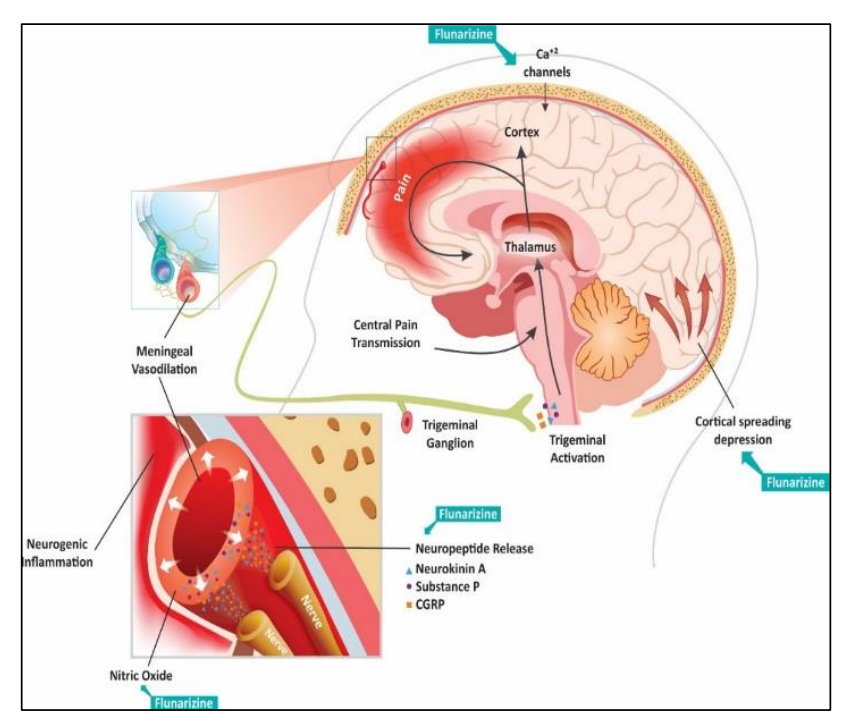

Figure 1: Various mechanisms of migraine targeted by flunarizine.

\section{Cortical spreading depression and channelopathy}

Cortical spreading depression and associated aura phase of the migraine is caused by enhanced activity of P/Qtype calcium channels. ${ }^{10}$ Flunarizine blocks these channels and raises the excitability threshold in spreading depression. $^{11}$

\section{Neurogenic inflammation and channelopathy}

It involves release of vasoactive neuropeptides (calcitonin gene-related peptide, (CGRP) substance $\mathrm{P}$ and neurokinin A) that cause inflammatory tissue responses such as arteriolar vasodilation, plasma protein extravasation, and degranulation of mast cells. ${ }^{12,13}$

Flunarizine is effective in the prevention of neurogenic inflammation by blocking the calcium channel dependent release of these neuropeptides. ${ }^{14}$ 


\section{Flunarizine: long term efficacy}

In a 24-month follow-up of patients with migraine receiving flunarizine (10 $\mathrm{mg}$ once daily), $72 \%$ of participants were responders (decrease in the headache index by $\geq 60 \%$ ) at 9th month without serious adverse events been reported. ${ }^{15}$

\section{Flunarizine: efficacy after discontinuation}

In a single blind randomized study, patients receiving prophylactic flunarizine (10 $\mathrm{mg}$ once daily, $\mathrm{n}=25)$ or nimodipine ( $40 \mathrm{mg}$ thrice a day, $\mathrm{n}=25$ ) for 6 month, after discontinuation of prophylactic dosing, the positive effect of treatment retained on average for 8 months in the flunarizine group and for 5 months in the nimodipine $(\mathrm{p}<0.05)$ group.

The longer retention of antimigraine effect in patients receiving flunarizine indicate that the site of action of the drug is neuronal rather than vascular, which involve slow rearrangement of central process in migraine. ${ }^{16}$
In another study, in patients with migraine $(n=367)$ receiving flunarizine (10 $\mathrm{mg}$ once daily) for 6 months, at 3 and 6 months follow-ups after treatment discontinuation, Global Evaluation Scale values were maintained at $64.6 \%$ and $61.3 \%$, respectively, which were below the baseline value $(\mathrm{p}<0.0001)$. The results suggested considerable retention of antimigraine activity 6 months after discontinuation of flunarizine treatment. ${ }^{17}$ Since this was an open-label study, the results should not be extrapolated to all the patients.

\section{Flunarizine vs other anti-migraine drugs}

Studies comparing efficacy and safety of flunarizine with other prophylactic drugs used for migraine such as propranolol, topiramate, amitriptyline and valproate suggest that efficacy of flunarizine is comparable to that of other antimigraine drugs (Table 2). Some of the former trials conducted with flunarizine have shortcomings in their design. They have included patients with older definition of migraine, not used intention-to-treat analysis and are non-randomized.

Table 2: Comparative efficacy and safety studies of flunarizine.

\begin{tabular}{|c|c|c|c|}
\hline Study & Duration & Efficacy & Conclusion \\
\hline $\begin{array}{l}\text { Lücking } \\
\text { et } \mathrm{al}^{37}\end{array}$ & 4 months & $\begin{array}{l}\downarrow \text { in the average number and duration of attacks in } \\
\text { both FLU and PROP group was similar. }\end{array}$ & $\begin{array}{l}\text { FLU and PROP had similar efficacy } \\
\text { profile in migraine prophylaxis. }\end{array}$ \\
\hline $\begin{array}{l}\text { Ludin } \\
\text { et al. }{ }^{38}\end{array}$ & 4 months & $\begin{array}{l}1 . \downarrow \text { in the number of attacks: } \\
\text { FLU }=48.1 \%, \text { PROP }=50.0 \% \\
\text { 2. } \downarrow \text { in the duration of attacks: } \\
\text { FLU }=22.2 \%, \text { PROP }=31.2 \% \\
\text { 3. } \downarrow \text { in the intensity of migraine attacks: FLU }=22.2 \% \text {, } \\
\text { PROP }=28.1 \% \\
\text { 4. Consumption of analgesics during the migraine } \\
\text { attacks: FLU }=66.6 \% \text {. } \\
\text { PROP }=62.4 \%\end{array}$ & $\begin{array}{l}\text { Efficacy and safety profile of both the } \\
\text { PROP and FLU were comparable. }\end{array}$ \\
\hline $\begin{array}{l}\text { Shimell } \\
\text { et al. }\end{array}$ & 4 months & $\begin{array}{l}\text { Both the groups had 4-fold decrease in the migraine } \\
\text { attack frequency. }\end{array}$ & $\begin{array}{l}\text { Both FLU and PROP were effective. } \\
\text { FLU had lesser safety concerns. }\end{array}$ \\
\hline $\begin{array}{l}\text { Gawel } \\
\text { et al. }{ }^{40}\end{array}$ & 4 months & Positive responders: $\mathrm{FLU}=67 \%$ and $\mathrm{PROP}=51 \%$ & $\begin{array}{l}\text { Efficacy of both FLU and PROP were } \\
\text { comparable. } \\
\text { FLU may have a better safety profile. }\end{array}$ \\
\hline $\begin{array}{l}\text { Bordini } \\
\text { et al. }{ }^{41}\end{array}$ & 4 months & $\begin{array}{l}\text { 1. Migraine index: PROP }=23.4^{*}, \mathrm{FLU}=18.7^{*} \text { and both } \\
\text { drugs }=14.4^{*} \text {. } \\
\text { 2. Mean frequency of attacks: } \\
\mathrm{PROP}=1.26^{* *}, \mathrm{FLU}=1.2^{* *} \text { and both drugs }=1.13^{* *} \\
\left({ }^{*} \mathrm{p}<0.05,{ }^{* *} \mathrm{p}<0.01\right)\end{array}$ & $\begin{array}{l}\text { Efficacy across treatment groups was } \\
\text { similar. The therapeutic effect was } \\
\text { maintained for up to } 45 \text { days of } \\
\text { flunarizine after drug withdrawal. }\end{array}$ \\
\hline $\begin{array}{l}\text { Diener } \\
\text { et al. }{ }^{42}\end{array}$ & 4 months & $\begin{array}{l}\% \text { responders: } \\
\text { FLU } 5 \mathrm{mg}=46 \% \text {, } \\
\text { FLU } 10 \mathrm{mg}=53 \%, \text { PROP }=48 \%\end{array}$ & $\begin{array}{l}\text { FLU efficacy was noninferior compared } \\
\text { with PROP. }\end{array}$ \\
\hline $\begin{array}{l}\text { Luo } \\
\text { et al. }{ }^{43}\end{array}$ & 12 months & $\begin{array}{l}\text { 1. } \downarrow \text { in the monthly headache frequency by }>50 \% \text { : } \\
\text { FLU }=66.7 \% \text {; } \\
\text { TOP }=72.7 \% \text {; }\end{array}$ & Both FLU and TOP were effective. \\
\hline $\begin{array}{l}\text { Gracia- } \\
\text { Naya } \\
\text { et al. }{ }^{44}\end{array}$ & 4 months & $\begin{array}{l}\text { 1. } \downarrow \text { in the frequency of migraine attacks: } \\
\text { TOP }=59 \% \text {; FLU }=58.5 \% \\
\text { 2. Responders: } \\
\text { TOP }=57 \% \text {; FLU }=64 \% \\
\text { 3. Treatment satisfaction: TOP }=78.9 \% \text {; FLU }=75 \%\end{array}$ & $\begin{array}{l}\text { Both FLU and TOP had similar efficacy } \\
\text { profile. }\end{array}$ \\
\hline
\end{tabular}

FLU: Flunarizine, PROP: Propranolol, TOP: Topiramate 


\section{Flunarizine: use of low dose}

In a randomized study, patients with migraine were treated with an initial single evening dose of flunarizine of $5 \mathrm{mg}$ (group A) and $10 \mathrm{mg}$ (group B) for a period of 2 months, which was then reversed. Each of the subsequent treatment periods lasted 2 months. Flunarizine proved to be efficacious in $80 \%$ of the patients initially treated (first 2 months) with the dose of $5 \mathrm{mg} /$ day and in $90 \%$ of those treated with the dose of $10 \mathrm{mg} /$ day..$^{18}$

The analytic evaluation of the headache parameters of the group B already showed a significant decrease at the end of the first 2 month course of treatment; the results did not change when the patients passed on to the following course of treatment in which they received $5 \mathrm{mg}$ daily dose. The group A patients who were initially treated with flunarizine $5 \mathrm{mg}$ showed a significant decrease only for few headache parameters in the first 2 month course of treatment; however, the following course with flunarizine $10 \mathrm{mg}$ caused a significant decrease in all the parameters considered.

Prodromes disappeared in $58 \%$ of the cases in group A and after following treatment with flunarizine $10 \mathrm{mg}$, both prodromes and accompanying symptoms disappeared in $100 \%$ of the cases. ${ }^{18}$

In group B, the side effects seen were weight gain $(3.5 \mathrm{~kg}$ on average over 2 months) and tiredness. The appetite gain and tiredness decreased on shifting the patients to 5 mg. In group A, the side effects seen were weight gain (1 $\mathrm{kg}$ on average over 1 month) and slight tiredness, which spontaneously disappeared after the first 30 days of therapy. Shifting to doses of $10 \mathrm{mg} /$ day caused increase in weight gain (4 $\mathrm{kg}$ on average over 2 months). ${ }^{18}$

The drug is more efficacious at the dose of $10 \mathrm{mg} / \mathrm{day}$. Side effects, however, occurred more frequently during treatment with flunarizine at the dose of $10 \mathrm{mg} /$ day.

The lower incidence of side effects with doses of 5 $\mathrm{mg} /$ day may be due to a dose-dependent receptor stimulation. The authors suggested the use of $5 \mathrm{mg} /$ day of flunarizine when migraine is not too severe and when obesity prevents use at the "classical" dose of $10 \mathrm{mg} .{ }^{18}$

\section{Flunarizine: role in different types of migraine}

\section{Vestibular migraine}

Vestibular migraine presents with attacks of spontaneous or positional vertigo, head motion-induced vertigo, and visual vertigo lasting 5 minutes to 3 days. It is observed in $9 \%$ of patients with migraine. ${ }^{19}$ The Canadian Headache Society (CHS) recommends the use of flunarizine for the management of vestibular migraine ${ }^{9}$ The clinical evidence demonstrated efficacy of flunarizine in vestibular migraine and are in concordance with the recommendations of CHS. (Table 3)

\section{Childhood migraine}

Migraine is commonly observed in children with a prevalence of $5 \%$ in children of 7 to 10 years and $17 \%$ in adolescents. ${ }^{20,21}$ It is important to diagnose brief migraine attacks in children with less than one-hour duration and differentiate them from episodic tension type headaches. $^{22}$ American Academy of Neurology guidelines for childhood migraine recommend the use of flunarizine. ${ }^{23}$ Studies show that, flunarizine demonstrates good efficacy in the management of childhood migraine. (Table 3) Based on these evidences, flunarizine may be considered the drug of first choice for childhood migraine. Flunarizine $5 \mathrm{mg}$ daily (at night) is the recommended dose for children aged 6 to 17 years of age.

\section{Abdominal migraine}

Abdominal migraine, an idiopathic recurrent disorder, is predominantly observed in children and has characteristic episodic midline umbilical pain and nausea/vomiting. Patients with abdominal migraine are often misdiagnosed for appendicitis, gastritis, worm infestation or food intolerance. ${ }^{24}$ For the management of gastrointestinal disorders in migraine, prophylactic antimigraine therapy is recommended. Clinical studies demonstrated that prophylactic treatment with flunarizine is effective for the management of abdominal migraine (Table 3 ).

\section{Hemiplegic migraine}

Hemiplegic migraine is a migraine with aura including motor weakness. ${ }^{25}$ For the management of hemiplegic migraine a prophylactic therapy is essential. Clinical studies indicate that flunarizine could be a beneficial option for prophylactic management of flunarizine (Table 3).

\section{Flunarizine: safety concerns and their management}

Flunarizine is a lipophilic, poorly water-soluble molecule that has a high blood brain barrier permeability and potential to interact with the neurotransmitters causing side effects. ${ }^{26}$ The adverse effects associated with flunarizine are drowsiness, weight gain, extrapyramidal side effects and depression. However, these side effects are manageable by selection of appropriate dose, giving drug holidays, prescribing the drug at night and avoiding its use in older individuals ( $>60$ years). (Table 4 )

In a 24-month follow-up of migraine patients receiving flunarizine (10 mg once daily), drowsiness and weight gain (mean $4.7 \mathrm{~kg}$ ) were commonly reported. Drowsiness was perceived more in the 1 st month and diminished progressively with a significant reduction at the end of therapy. Depressive symptoms were reported in 9 cases (out of 120 patients). Six out of these required short-term pharmacological treatments and recovered within 4-6 weeks. Three out of these 6 cases had history of mood disorders. ${ }^{15,27}$ 
A post-marketing study was designed to evaluate the safety of flunarizine in routine clinical practice (3186 patients). Overall, extrapyramidal symptoms were noted in only four patients and total 41 patients developed depression. Additional risk factors for depression were a history of depression and a high number of previous migraine treatments. Another prospective, open-label, multicenter study conducted to evaluate the risk/benefit ratio of flunarizine in patients with migraine or vertigo demonstrated a significantly higher incidence of depression in the flunarizine group than in the propranolol group during the follow-up phase of the study. However, extrapyramidal symptoms were not observed. ${ }^{28}$

Table 3: Efficacy of flunarizine in different migraine types.

\begin{tabular}{|c|c|c|c|}
\hline Study & Study details & Results & Conclusion \\
\hline \multicolumn{4}{|c|}{ Vestibular migraine } \\
\hline $\begin{array}{l}\text { Lepcha } \\
\text { et al. }{ }^{45}\end{array}$ & $\begin{array}{l}\text { Group 1: Flunarizine (10 mg } \\
\text { daily) + betahistine (16 mg thrice } \\
\text { a day) + paracetamol ( } 1 \mathrm{gm} \text { daily }) \\
\text { Group } 2 \text { : Betahistine }(16 \mathrm{mg} \\
\text { thrice a day) + paracetamol ( } 1 \mathrm{gm} \\
\text { daily) Duration: } 12 \text { weeks }\end{array}$ & $\begin{array}{l}\text { Improvement in episodes }(\mathrm{p}=0.010) \\
\text { and frequency }(\mathrm{p}=0.046) \text { of vestibular } \\
\text { migraine in flunarizine group. }\end{array}$ & $\begin{array}{l}\text { Flunarizine is effective in } \\
\text { vestibular migraine. }\end{array}$ \\
\hline Liu et al. ${ }^{46}$ & $\begin{array}{l}\text { Treatment: Venlafaxine or } \\
\text { valproic acid or flunarizine } \\
\text { Duration: } 3 \text { months }\end{array}$ & $\begin{array}{l}\text { Improvement in dizziness handicap } \\
\text { inventory score }(\mathrm{p}=0.019) \text { and vertigo } \\
\text { severity score }(\mathrm{p}=0.03) \text { in patients } \\
\text { receiving flunarizine }\end{array}$ & $\begin{array}{l}\text { Flunarizine has better } \\
\text { efficacy compared with } \\
\text { venlafaxine and valproic } \\
\text { acid. }\end{array}$ \\
\hline \multicolumn{4}{|c|}{ Childhood migraine } \\
\hline $\begin{array}{l}\text { Visudtibha } \\
\text { n et al. }{ }^{47}\end{array}$ & $\begin{array}{l}\text { Age: } 7 \text { to } 15 \text { years } \\
\text { Flunarizine: } 5 \mathrm{mg} \text { or } 10 \mathrm{mg}\end{array}$ & $\begin{array}{l}\text { No recurrent migraine: } 23 \% \\
>50 \% \text { reduction in the migraine } \\
\text { frequency: } 42 \%\end{array}$ & $\begin{array}{l}\text { Flunarizine was effective in } \\
\text { the treatment of childhood } \\
\text { migraine. }\end{array}$ \\
\hline $\begin{array}{l}\text { Guidetti } \\
\text { et al. }{ }^{48}\end{array}$ & $\begin{array}{l}\text { Age: } 10 \text { to } 13 \text { years } \\
\text { Flunarizine: } 5 \mathrm{mg} \\
\text { Duration: } 2 \text { months }\end{array}$ & $\begin{array}{l}\text { Flunarizine decreased migraine } \\
\text { frequency, without affecting human } \\
\text { growth hormone, thyrotropin releasing } \\
\text { hormone, and HbA1c levels }\end{array}$ & $\begin{array}{l}\text { Flunarizine decreased the } \\
\text { childhood migraine } \\
\text { frequency, without major } \\
\text { safety concerns. }\end{array}$ \\
\hline $\begin{array}{l}\text { Kim et } \\
\text { al. }^{49}\end{array}$ & $\begin{array}{l}\text { Age: } 9 \text { to } 15 \text { years } \\
\text { Flunarizine: } 5 \mathrm{mg} \\
\text { Duration: } \sim 6 \text { months }\end{array}$ & $\begin{array}{l}\text { 1. Responder rate: } \\
\text { FLU }=80 \%, \text { TOP }=81 \% \\
\text { 2. Retention rate: } \\
\text { FLU }=67 \%, \text { TOP }=63 \%\end{array}$ & $\begin{array}{l}\text { Flunarizine was efficacious } \\
\text { in the management of } \\
\text { childhood migraine and did } \\
\text { not have major side effects. }\end{array}$ \\
\hline $\begin{array}{l}\text { Mohamed } \\
\text { et al. }{ }^{50}\end{array}$ & $\begin{array}{l}\text { Age: } 1.5 \text { years to } 17 \text { years } \\
\text { Flunarizine: } 2.5 \mathrm{mg} \text { to } 10 \mathrm{mg} \\
\text { Duration: } 12 \text { months }\end{array}$ & $\begin{array}{l}\text { Number of patients with }>50 \% \\
\text { reduction in the frequency of migraine: } \\
57 \%\end{array}$ & $\begin{array}{l}\text { Children receiving } \\
\text { flunarizine demonstrated } \\
\text { notable reduction in the } \\
\text { migraine frequency and } \\
\text { acceptable tolerability. }\end{array}$ \\
\hline \multicolumn{4}{|c|}{ Abdominal migraine } \\
\hline $\begin{array}{l}\text { Boccia } \\
\text { et al. }\end{array}$ & $\begin{array}{l}\text { Treatment: } \\
\text { Flunarizine ( } 5 \mathrm{mg}, \text { o.d.) }\end{array}$ & $\begin{array}{l}\text { Reduction in: } \\
\text { Headache- frequency }(\mathrm{p}<0.05) \text { duration } \\
(\mathrm{p}<0.01) \text {; } \\
\text { Total gastric emptying time }(\mathrm{p}=0.002) \text {, } \\
\text { Abdominal pain }(\mathrm{p}<0.001), \\
\text { Vomiting per month }(\mathrm{p}<0.01)\end{array}$ & $\begin{array}{l}\text { Flunarizine alleviated the } \\
\text { gastrointestinal symptoms } \\
\text { of migraine in children. }\end{array}$ \\
\hline $\begin{array}{l}\text { Kothare } \\
\text { et al. } 52\end{array}$ & $\begin{array}{l}\text { Cyclic vomiting syndrome: } 5 \mathrm{mg} \text {; } \\
\text { Abdominal migraine: } 7.5 \mathrm{mg}\end{array}$ & $\begin{array}{l}\text { Reduction in, } \\
\text { Cyclic vomiting syndrome: frequency } \\
(57 \%) \text { and duration }(44 \%) \text {; } \\
\text { Abdominal migraine: frequency }(61 \%) \\
\text { and duration }(51 \%)\end{array}$ & $\begin{array}{l}\text { Flunarizine was efficacious } \\
\text { in the management of } \\
\text { abdominal symptoms of } \\
\text { migraine. }\end{array}$ \\
\hline \multicolumn{4}{|c|}{ Hemiplegic migraine } \\
\hline $\begin{array}{l}\text { Mohamed } \\
\text { et al. }{ }^{50}\end{array}$ & $\begin{array}{l}\text { Treatment: Flunarizine } \\
\text { Duration: } 12 \text { months }\end{array}$ & $\begin{array}{l}\geq 50 \% \text { reduction in attack frequency in } \\
\text { patients with, } \\
\text { Hemiplegic migraine: } 80 \% \\
\text { Non-hemiplegic migraine: } 57 \%\end{array}$ & $\begin{array}{l}\text { Flunarizine had a better } \\
\text { efficacy in the patients with } \\
\text { hemiplegic migraine than } \\
\text { with non-hemiplegic } \\
\text { migraine }\end{array}$ \\
\hline
\end{tabular}

FLU: flunarizine; TOP: topiramate 
Table 4: Flunarizine side effects and their management.

\begin{tabular}{|c|c|c|}
\hline Side effect & Proposed mechanism & Management \\
\hline $\begin{array}{l}\text { Weight gain associated } \\
\text { with increased appetite }\end{array}$ & $\begin{array}{l}\text { 5-HT antagonism and NA } \\
\text { reuptake inhibition and } \\
\text { resistance to leptin } \\
\text { hormone }\end{array}$ & $\begin{array}{l}\text { Start with } 5 \mathrm{mg} \text { in first month before using } 10 \mathrm{mg} \\
\text { Advise patient to follow his or her usual diet without any } \\
\text { increase in portion size from day one of therapy } \\
\text { Record weight at start and on each follow up }\end{array}$ \\
\hline $\begin{array}{l}\text { Extrapyramidal side } \\
\text { effects }^{54}\end{array}$ & $\begin{array}{l}\text { Pre-synaptic (loss of } \\
\text { tyrosine hydroxylase in } \\
\text { monoaminergic and } \\
\text { serotonergic neurons } \\
\text { leading to dopamine } \\
\text { depletion) and post- } \\
\text { synaptic one's factors } \\
\text { (blocking striatal } \\
\text { dopaminergic receptors) }\end{array}$ & $\begin{array}{l}\text { Not to be prescribed in patients with history of pre-existing } \\
\text { symptoms of Parkinson's disease or other extrapyramidal } \\
\text { disorders } \\
\text { Avoid use in elderly patients ( }>60 \text { years) } \\
\text { If the patient responds satisfactorily after } 3 \text { months of } \\
\text { therapy and if a maintenance treatment is needed, the } \\
\text { dosage schedule should be changed. Each week the patient } \\
\text { should receive } 5 \text { days of treatment at the same daily dose } \\
\text { and } 2 \text { successive drug-free days (Drug Holidays). }\end{array}$ \\
\hline $\begin{array}{l}\text { Depression, mood } \\
\text { swings } 55,56\end{array}$ & Imbalance in 5-HT and NA & $\begin{array}{l}\text { Not to be prescribed in patients with history of depressive } \\
\text { illness } \\
\text { Sequential treatment with drug holidays }\end{array}$ \\
\hline $\begin{array}{l}\text { Drowsiness or } \\
\text { Somnolence }^{55,57}\end{array}$ & Antihistaminic action & $\begin{array}{l}\text { Always give the drug at night-time } \\
\text { Start with } 5 \mathrm{mg} \text { in first month before using } 10 \mathrm{mg} \text {. } \\
\text { At the start of the treatment, patient should be cautioned } \\
\text { during activities such as driving or operating dangerous } \\
\text { machinery }\end{array}$ \\
\hline
\end{tabular}

5-HT: 5-hydroxy tryptamine; NA: noradrenalin

\section{DISCUSSION}

Flunarizine is effective in the prophylactic management of migraine, suggesting its multimodal mechanism of action. Clinical evidence suggests that efficacy of flunarizine is comparable to those of first-line drugs such as topiramate, propranolol and divalproex sodium.

Flunarizine has shown efficacy in a wide range of migraine types such as hemiplegic migraine, abdominal migraine, vestibular migraine and childhood migraine. Long-term prophylactic treatment of flunarizine is marked by a significant decline in the frequency and severity of the disease with manageable side-effects. After three decades since its first use, flunarizine remains a useful treatment option for migraine.

\section{ACKNOWLEDGEMENTS}

Authors would like to thank Rahul Nikam and Rukhsar Wasta for providing manuscript writing assistance.

Funding: The manuscript writing services used for the review have been funded by Janssen India, Johnson \& Johnson Private Limited.

Conflict of interest: None declared

Ethical approval: Not required

\section{REFERENCES}

1. Burstein R, Noseda R, Borsook D. Migraine: Multiple Processes, Complex Pathophysiology. J Neurosci. 2015;35(17):6619-29.
2. Kulkarni G, Rao G, Gururaj G, Subbakrishna DK, Steiner T, Stovner LJ. EHMTI-0333. The prevalence and burden of migraine in india: results of a population-based study in Karnataka state. J Headache Pain. 2014;15(Suppl 1):B18.

3. Ray BK, Paul N, Hazra A, Das S, Ghosal MK, Misra AK, et al. Prevalence, burden, and risk factors of migraine: A community-based study from Eastern India. Neurol India. 2017;65:1280-8.

4. Francis MV. High prevalence of migraine in women in a south Indian coastal population. Po136. Cephalalgia. 2009;29:64-5.

5. Migraine prophylaxis: flunarizine. Evidence summary [ESUOM33]; Published date: September 2014. Available at: https://www.nice.org.uk/advice/esuom33/chapter/K ey-points-from-the-evidence. Accessed on 9 December 2019.

6. Gelmers HJ. Calcium-channel blockers in the treatment of migraine. Am J Cardiol. 1985;55:139b43.

7. Treatment Guideline Subcommittee of the Taiwan Headache Society. [Treatment guidelines for preventive treatment of migraine]. Acta Neurol Taiwan. 2008;17(2):132-48.

8. Evers S, Afra J, Frese A, Goadsby PJ, Linde M, May A, et al. EFNS guideline on the drug treatment of migraine--revised report of an EFNS task force. Eur J Neurol. 2009;16:968-81.

9. Pringsheim $\mathrm{T}$, Davenport $\mathrm{W}$, Mackie G, Worthington I, Aube M, Christie SN, et al. Canadian Headache Society guideline for migraine prophylaxis. Can J Neurol Sci. 2012;39(2 Suppl 2):S1-59. 
10. Tottene A, Conti R, Fabbro A, Vecchia D, Shapovalova M, Santello M, et al. Enhanced excitatory transmission at cortical synapses as the basis for facilitated spreading depression in $\mathrm{Ca}(\mathrm{v}) 2.1$ knockin migraine mice. Neuron. 2009;61:762-73.

11. Eikermann-Haerter K, Can A, Ayata C. Pharmacological targeting of spreading depression in migraine. Expert Rev Neurother. 2012;12(3):297306.

12. Raddant AC, Russo AF. Calcitonin gene-related peptide in migraine: intersection of peripheral inflammation and central modulation. Expert Rev Mol Med. 2011;13:e36.

13. Tajti J, Szok D, Majlath Z, Tuka B, Csati A, Vecsei L. Migraine and neuropeptides. Neuropeptides. 2015;52:19-30.

14. Hashimoto M, Yamamoto Y, Takagi H. Effects of KB-2796 on plasma extravasation following antidromic trigeminal stimulation in the rat. Res Commun Mol Pathol Pharmacol. 1997;97:79-94.

15. Bono G, Manzoni GC, Martucci N, Baldrati A, Farina S, Cassabgi F, et al. Flunarizine in common migraine: Italian cooperative trial. II. Long-term follow-up. Cephalalgia. 1985;5:155-158.

16. Nuti A, Lucetti C, Pavese N, Dell'Agnello G, Rossi G, Bonuccelli U. Long-term follow-up after flunarizine or nimodipine discontinuation in migraine patients. Cephalalgia. 1996;16(5):337-40.

17. Martinez-Lage JM. Flunarizine (Sibelium) in the prophylaxis of migraine. An open, long-term, multicenter trial. Cephalalgia. 1988;8:15-20.

18. Centonze V, Magrone D, Vino M, Caporaletti P, Attolini E, Campanale G, et al. Flunarizine in migraine prophylaxis: efficacy and tolerability of 5 $\mathrm{mg}$ and $10 \mathrm{mg}$ dose levels. Cephalalgia. 1990;10:1724.

19. Lempert T, Neuhauser H. Epidemiology of vertigo, migraine and vestibular migraine. $J$ Neurol. 2009;256:333-8.

20. Aydin M, Kabakus N, Bozdag S, Ertugrul S. Profile of children with migraine. Indian $\mathrm{J}$ Pediatr. 2010;77:1247-51.

21. Barnes N, Millman G, James E. Migraine headache in children. Clin Evid. 2005:388-95.

22. Francis MV. Brief migraine episodes in children and adolescents-a modification to International Headache Society pediatric migraine (without aura) diagnostic criteria. Springer Plus. 2013;2:77.

23. Lewis D, Ashwal S, Hershey A, Hirtz D, Yonker M, Silberstein S. Practice parameter: pharmacological treatment of migraine headache in children and adolescents: report of the American Academy of Neurology Quality Standards Subcommittee and the Practice Committee of the Child Neurology Society. Neurology. 2004;63:2215-24.

24. Francis MV. Episodic Syndromes That May Be Associated with Migraine-Two Clinically Useful Markers. J Headache Pain Management. 2016;1:10.
25. Headache Classification Committee of the International Headache Society (IHS) The International Classification of Headache Disorders, $3^{\text {rd }}$ Ed. Cephalalgia. 2018;38:1-211.

26. Leone M, Grazzi L, La Mantia L, Bussone G. Flunarizine in migraine: a minireview. Headache. 1991;31:388-91.

27. Colucci D'Amato C, Colucci D'Amato A, Alfano V, Giordano E, Marmo E. Flunarizine in long-term migraine prophylaxis: clinical evidence. J Med. 1990;21:201-7.

28. De Bock G, Eelhart J, Van Marwijk H, Tromp T, Springer M. A postmarketing study of flunarizine in migraine and vertigo. Pharm World Sci. 1997;19(6):269-74.

29. Diener HC, Holle-Lee D, Nagel S, Dresler T, Gaul $\mathrm{C}$, Gobel H, et al. Treatment of migraine attacks and prevention of migraine: Guidelines by the German Migraine and Headache Society and the German Society of Neurology. Clin Translational Neuroscience. 2019; 1:1-40.

30. Sarchielli P, Granella F, Prudenzano MP, Pini LA, Guidetti V, Bono $G$ et al. Italian guidelines for primary headaches: 2012 revised version. J Headache Pain. 2012;13:S31-70.

31. Bendtsen L, Birk S, Kasch H, Pini LA, Guidetti V, Bono G, et al. Reference programme: Diagnosis and treatment of headache disorders and facial pain. Danish Headache Society, $2^{\text {nd }}$ Ed 2012. J Headache and Pain. 2012;13:1-29.

32. Migraine prophylaxis: flunarizine. Evidence summary [ESUOM33]; Published date: September 2014. Available at: https://www.nice.org.uk/advice/esuom33/chapter/K ey-points-from-the-evidence. Accessed on 9 December 2019.

33. Clinical Practice Guidelines. Diagnosis and Management of Headache by Ministry of Health, Singapore. 2007. Available at: https://www.moh.gov.sg/docs/librariesprovider4/gui delines/cpg_headache_booklet.pdf Accessed on 9 December 2019.

34. Ravishankar K, Chakravarty A, Chowdhury D, Shukla R, Singh S. Guidelines on the diagnosis and the current management of headache and related disorders. Ann Indian Acad Neurol. 2011;14:S4059.

35. Victor S, Ryan SW. Drugs for preventing migraine headaches in children. Cochrane Database Syst Rev. 2003:Cd002761.

36. Goadsby PJ. Migraine and Other Primary Headache Disorders. In: Jameson JL, Fauci A, Kasper D, Hauser S, Longo D, Loscalzo J. Harrison's Principles of Internal Medicine. 20 ${ }^{\text {th }}$ Ed.: McGraw Hill Education Medical; 2018:3096-3108.

37. Lucking $\mathrm{CH}$, Oestreich W, Schmidt R, Soyka D. Flunarizine vs. propranolol in the prophylaxis of migraine: two double-blind comparative studies in more than 400 patients. Cephalalgia. 1988;8:21-6. 
38. Ludin HP. Flunarizine and propranolol in the treatment of migraine. Headache: J Head Face Pain. 1989;29:219-24.

39. Shimell C, Fritz V, Levien S. A comparative trial of flunarizine and propranolol in the prevention of migraine. S Afr Med J. 1990;77(2):75-7.

40. Gawel MJ, Kreeft J, Nelson RF, Simard D, Arnott WS. Comparison of the efficacy and safety of flunarizine to propranolol in the prophylaxis of migraine. Can J Neurol Sci. 1992;19:340-5.

41. Bordini CA, Arruda MA, Ciciarelli MC, Speciali JG. Propranolol vs flunarizine vs flunarizine plus propranolol in migraine without aura prophylaxis. A double-blind trial. Arquivos de neuro-psiquiatria. 1997;55:536-41.

42. Diener HC, Matias-Guiu J, Hartung E, Pfaffenrath V, Ludin HP, Nappi G et al. Efficacy and tolerability in migraine prophylaxis of flunarizine in reduced doses: a comparison with propranolol 160 mg daily. Cephalalgia. 2002;22:209-21.

43. Luo N, Di W, Zhang A, Wang Y, Ding M, Qi W, et al. A randomized, one-year clinical trial comparing the efficacy of topiramate, flunarizine, and a combination of flunarizine and topiramate in migraine prophylaxis. Pain Med. 2012;13:80-6.

44. Gracia-Naya M, Rios C, García-Gomara M, Sanchez-Valiente S, Mauri-Llerda JA, SantosLasaosa S, et al. A comparative study of the effectiveness of topiramate and flunarizine in independent series of chronic migraine patients without medication abuse. Revista de Neurologia. 2013;57:347-53.

45. Lepcha A, Amalanathan S, Augustine AM, Tyagi AK, Balraj A. Flunarizine in the prophylaxis of migrainous vertigo: a randomized controlled trial. Eur Arch Otorhinolaryngol. 2014;271:2931-6.

46. Liu F, Ma T, Che X, Wang Q, Yu S. The Efficacy of Venlafaxine, Flunarizine, and Valproic Acid in the Prophylaxis of Vestibular Migraine. Frontiers in Neurol. 2017;8:524.

47. Visudtibhan A, Lusawat A, Chiemchanya S, Visudhiphan P. Flunarizine for prophylactic treatment of childhood migraine. J Med Assoc Thai. 2004;87:1466-70.
48. Guidetti V, Moscato D, Ottaviano S, Fiorentino D, Fornara R. Flunarizine and migraine in childhood. Cephalalgia. 1987;7:263-6.

49. Kim H, Byun SH, Kim JS, Lim BC, Chae JH, Choi $\mathrm{J}$, et al. Comparison of flunarizine and topiramate for the prophylaxis of pediatric migraines. Eur $\mathbf{J}$ Paediatr Neurol. 2013;17:45-9.

50. Peer Mohamed B, Goadsby PJ, Prabhakar P. Safety and efficacy of flunarizine in childhood migraine: 11 years' experience, with emphasis on its effect in hemiplegic migraine. Dev Med Child Neurol. 2012;54:274-7.

51. Boccia G, Del Giudice E, Crisanti AF, Strisciuglio C, Romano A, Staiano A. Functional gastrointestinal disorders in migrainous children: efficacy of flunarizine. Cephalalgia. 2006;26:12149.

52. Kothare SV. Efficacy of flunarizine in the prophylaxis of cyclical vomiting syndrome and abdominal migraine. Eur $\mathrm{J}$ Paediatr Neurol. 2005;9:23-6.

53. Berilgen MS, Bulut S, Gonen M, Tekatas A, Dag E, Mungen B. Comparison of the effects of amitriptyline and flunarizine on weight gain and serum leptin, $\mathrm{C}$ peptide and insulin levels when used as migraine preventive treatment. Cephalalgia. 2005;25:1048-53.

54. Lugaresi A, Montagna P, Gallassi R, Lugaresi E. Extrapyramidal syndrome and depression induced by flunarizine. Eur Neurol. 1988;28:208-11.

55. Abu-Arafeh I. Flunarizine for the prevention of migraine - a new look at an old drug. Dev Med Child Neurol. 2012;54:204-5.

56. Albani F, Baldrati A, Cortelli P, Riva R, Baruzzi A. Flunarizine plasma concentrations and side effects in migraine patients. Headache. 1990;30:369-70.

57. Bassi P, Brunati L, Rapuzzi B, Alberti E, Mangoni A. Low dose flunarizine in the prophylaxis of migraine. Headache. 1992;32:390-2.

Cite this article as: Francis MV, Singh S, Goyal V, Keny M. Flunarizine: a review of its role in migraine prophylaxis. Int J Res Med Sci 2020;8:786-93. 